views, which had considerable influence on Czech fre日 religious movements.

During his life Uzel collected at home and abroad much entomological material. This is deposited in the Prague Museum, the Agricultural Museum in Prague, the Natural History Museum in Vienna and in the Museum at Peradeniya. His collections in the Zoological Institute at Prague were destroyed by the Germans during the occupation of the country.

Altogether Uzel published some four hundred papers; a chronological survey of them has been published in Czech : "Work and Life of Prof. Dr. J. Uzel" (Prague, 1938).
K. ČẸMÁK
WE regret to announce the following deaths :

Mr. G. H. J. Adlam, O.B.E., editor since 1919 of the Scholl Science Review, on July 30, aged seventy.

My. Asa Binns, formerly chief engineer to the Port of London Authority, and a past president of the Institution of Mechanical Engineers, on July 2, aged seventy-two.

Sir Franeis Carnegie, C.B.E., during 1926-44 chief superintendent of ordnance factories, Royal Arsenal, Woolwich, on August 3, aged seventy-two.

Prof. J. Laird, regius professor of moral philosophy in the University of Aberdeen, on August 5, aged fifty-nine.
816

Mathematical Physics at Cambridge:

Prof. D. R. Hartree, F.R.S.

Prof. D. R. HÁrtree, who has been appointed Plummer professor of mothematical physics in the University of Cambrify, in succession to the late Sir Ralph Fowlepus born in 1897 and educated at Bedales. Durifg the First World War he was a lieutengn in the R.N.V.R., and worked at the Afti-A Mraft Experimental Section at Whale Island af 1 member of a famous team of scientific men under the direction of Prof. A. V. Hill. Going to Cambridge, he took the Natural Sciences Tripos in 1922 and was elected a fellow of St. John's College in 1924. After one year (1928-29) as University demonstrator in physics, Hartree was elected Beyer professor of applied mathematics in the University of Manchester, which post he held until 1937, when he became professor of theoretical physics in the Physical Laboratory at Manchester.

Prof. Hartree's earlier work was mainly connected with the calculation of the energy-levels and wavefunctions of atomic structures. He possesses a great gift and liking for numerical mathematics, and this aptitude he displayed to the full in this field, which he has made peculiarly his own. Later on, when he felt that he had sufficiently exploited 'pencil and paper' methods, he decided that a differential analyser was needed to develop the work further. Taking as a model that of Prof. Bush at the Massachusetts Institute of Technology, a differential analyser was built by Metropolitan-Vickers for Prof. Hartree and housed in the Physical Laboratories, Manchester. This instrument, the first made in Great Britain, has been used for very many other purposes than calculating atomic properties. For example, it has been fully employed during 1939-45 on technical problems for the Services and for industry. During the Second World War, Hartree was employed by the Ministry of Supply on very many problems of importance, particularly in the field of internal ballistics of rockets, of the propagation of radio waves, and of the theory of the magnetron. He was chairman of the Ministry of Supply Panel on servo mechanisms, which has played a very valuable part in co-ordinating work on servo mechanism throughout Great Britain. In 1939 he gave the Kelvin Lecture to the Institution of Electrical Engineers. Recently Hartree's interests in calculating machines have led him to study American work on electronic calculators. $\mathrm{He}$ has just returned from a visit to the United States, where he worked at the University of Pennsylvania with the E.N.I.A.C. (see Nature, April 20, p. 527). Hartree's appointment to the Cavendish Laboratory will bring him into touch with many fields of physies where his mathematical and computational ability will find full scope.

\section{Bacteriology at the University of Sheffield : Prof. C. P. Beattie}

Prof. C. P. Beatrie has been appointed professor of bacteriology in the University of Sheffield in succession to Prof. Wilson Smith, who recently left the University to occupy the chair of bacteriology at University College Hospital Medical School, London. Prof. Beattie was educated at Fettes College and the University of Edinburgh. After clinical and bacteriological experience in the hospitals and University of Edinburgh, he spent a period of study and research in the United States and in France with a Rockefeller fellowship, returning to Edinburgh to be lecturer in bacteriology in 1933. In 1937 he was appointed professor of bacteriology in the Royal Faculty of Medicine of Iraq and director of the Government Bacteriology Laboratory, Baghdad, which he started and organised as the bacteriological centre for the whole of Iraq, charged with the preparation of protective vaccines and sera as well as the conduct of bacteriological examinations. Prof. Beattie's own researches have covered a wide field of diseases, some common in Great Britain, some peculiar to Iraq; among his many other duties was the setting up of a quarantine laboratory for the examination of pilgrims returning from Mecca. Prof. Beattie will take up his duties at Sheffield at the beginning of October.

\section{Anti-Locust Research Centre

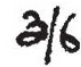

During the War, the Anti-Locust Research Centre concentrated on foregasting and advisory services for anti-locust campaings in Africa and the Middle East ; but now o/gnow for developing research activities has befferde under the Colonial Research and Eeve 60 ment Act, and Dr. D. L. Gunn, formerly of th University of Birmingham, has been appointed Intincipal scientific officer to take charge of this side of the work. It is hoped that the co-operation of university departments, mainly in zoology, can be enlisted, as funds are available to provide some grants to research students willing to undertake laboratory work on selected problems, or to take part in field investigations abroad, particularly in connexion with 